Article

\title{
Designing Learning for Sustainable Development: Digital Practices as Boundary Crossers and Predictors of Sustainable Lifestyles
}

\author{
Andreja Istenic Starcic ${ }^{1,2,3, *(1)}$, Maja Terlevic ${ }^{4}, \operatorname{Lin}_{\operatorname{Lin}}{ }^{3}(\mathbb{D})$ and Maja Lebenicnik ${ }^{2}$ \\ 1 Faculty of Civil and Geodetic Engineering, University of Ljubljana, Jamova 2, 1000 Ljubljana, Slovenia \\ 2 Faculty of Education, University of Primorska, Cankarjeva 5, 6000 Koper, Slovenia; m.lebenicnik@gmail.com \\ 3 College of Information, University of North Texas, 3940 N Elm St, Denton, TX 76207, USA; Lin.Lin@unt.edu \\ 4 Bella Vista d. o. o., Cerej 21, 6280 Ankaran, Slovenia; histra.maja@gmail.com \\ * Correspondence: andreja.starcic@gmail.com; Tel.: +386-31-629-906
}

Received: 10 May 2018; Accepted: 11 June 2018; Published: 15 June 2018

check for updates

\begin{abstract}
Sustainable development (SD) is a multidimensional issue. However, research findings report a divide between students' awareness and behavior. It is identified that study programs are designed more for awareness outcomes, and not so much for behavioral outcomes. For higher-order learning outcomes manifested in a sustainable development behavior, the authors argue for a model based on an understanding of learning as boundary crossing. Based on this model, learning for sustainable development occurs in relating social practices, lifestyles, academic practices, professional practices, and students' digital practices. To inform teachers' approaches to teaching as an important driver of institutional change, we conducted a survey among students of urban and spatial planning in Slovenia. Examined factors included personal, academic, and digital predictors for sustainable development awareness, lifestyle, and behavioral intention. We hypothesized that a significant predictor for sustainable development behavior, which was measured as sustainable lifestyle and sustainable development behavioral intention, would be learning in social practices, and that learning in social practices would predict preferred teaching methods. The findings of hierarchical regression analysis indicated personal factors as the most important predictors of SD behavioral intention, and academic predictors as the most important factors for SD awareness. Digital practices were found to be the most important predictors of a sustainable lifestyle. Social practices of sustainable lifestyle, digital practices, and perceived teaching methods predicted students' preferred teaching methods. We discuss the future directions of sustainable development education, considering digital social media practices as essential boundary crossers.
\end{abstract}

Keywords: sustainable development education; behavioral change; sustainable lifestyle; informal and formal learning; online social media

\section{Introduction}

Urban and spatial planning involves decision-making that integrates social development, economic efficiency, and diverse environmental issues. It has long-term effects on society, influencing human activity and social development, economic growth, and environmental resources [1]. Educating professionals to address these challenges requires higher-order learning outcomes that deal with sustainable development as a multidimensional issue. In taking these challenges into account, we argue for a model of learning as boundary crossing as the framework for developing procedural and problem-solving knowledge contextualized in real-life environments.

This paper first examines the multidimensional and relational perceptions of sustainable development issues in relation to higher-order learning outcomes. It reports the weak influence 
of higher education on sustainable behavior [2] and its application in professional practice [3]. We recommend approaches for facilitating sustainability and sustainable development (hereafter SD) using a whole-system approach that incorporates a SD academic culture $[4,5]$ that is connected to local and global contexts. We then discuss learning as boundary crossing, focusing on both academic-professional and academic-lifestyle boundaries. Informal education has been recognized as making significant contributions to learning in professional contexts, within authentic learning in the academic setting, and also in online learning via social media as a form of social capital. Digital social media practices and social networks as social capital support the integration of sustainability into higher education [6], and contribute to a whole-system approach [5] that connects the spheres of academic, professional, and personal lifestyle.

In the manuscript, we report findings examining the contribution of personal, academic and digital predictors to SD awareness, SD behavioral intention, sustainable lifestyle, and preferred teaching methods. We place our study within the SD education discussion of a divide between awareness and behavior, and discuss teaching approaches that can reduce the divide.

\subsection{The Multidimensional and Relational Perception of Sustainable Development Issues}

In urban and spatial planning, there is no single solution for problems that emerge in diverse developed and underdeveloped areas. While in the past, the focus has been on technical and economic feasibilities of design, in the future, sustainability engineering will require engagement in multidimensional issues [7]. Competent professionals need to be prepared for interaction in multidisciplinary communication and public debates, making decisions and acting to take into account a relational perception of SD and the notion that local biophysical and social space is influenced by global and virtual concerns [8]. SD is a worldwide issue, and the reform of higher education has a global focus, with the globalization of valued knowledge producing common definitions of educational inputs, intended learning outcomes, and international assessment $[9,10]$.

In recent decades, there has been a considerable focus on sustainable development education (hereafter SDE) and sustainability integration into higher education based on multidimensional and relational perspectives that take environmental, social, and economic issues into consideration [3]. The American Accreditation Board of Engineering and Technology [11] defined a set of professional skills consisting of process and awareness skills [12] that focus on SD [11]. The Bologna reform criteria for the accreditation of European engineering curricula also include SD [13].

The intended higher-order learning outcomes for SD in higher education is connected with self-reliance, self-directed learning, and real-life situations [14]. They consist of: solving complex problems, reflecting on the implications of their decisions, addressing current and future challenges [15], critical thinking [3], and collaborating with experts and stakeholders [14]. Thomas [16] highlighted the need for interdisciplinary thinking, problem-solving, teamwork, and holistic thinking. Shephard et al. [17] discussed higher-order affective outcomes for SD. Based on their comprehensive review of the literature, Wiek, Withycombe, and Redman [18] defined five critical thinking competencies for sustainability to be addressed in higher education: systems, normative, strategic, anticipatory, and interpersonal.

In summary, SD in higher education requires higher-order learning outcomes [19] that integrate conceptual, procedural, and problem-solving knowledge. At the level of cognitive strategies, learners regulate their own learning (self-reliance, self-directed learning), while at the level of developing attitudes, learners develop their cognitive, emotional, and social skills [20]. The literature refers interchangeably to sustainable development literacy [3] and sustainability literacy [16], which is the ability to apply SD in diverse areas of life. It refers to one's engagement, lifestyle, values, and understanding of local versus global aspects of phenomena [3]. It integrates high-conceptual, procedural, and problem-solving knowledge [19] that students apply in many areas of learning, which can include everyday life in unpredictable and problematic situations [3]. It also contributes to procedural knowledge for managing unexpected changes in a dynamically changing and complex 
world [3]. SD literacy requires the integration of skills, attitudes, dispositions, and values [21], as well as competences in the cognitive, emotional-affective, and behavioral domains. In comparison with abilities that are inherited and potentially influence operation, competencies are complex action systems that are useful in context-specific situations, and can be taught and learned [22]. Competencies reflect both personal capabilities and characteristics, as well as the characteristics of the work and contexts in which they are performed. In this paper, we discuss the authentic contexts of social practices and teaching and learning methods, as well as how students perceive them in relation to SD outcomes. First, we discuss outcomes.

\subsection{The Divide between Awareness and Behavior}

While Holdsworth and Hegarty's [15] research into SD learning outcomes in higher education indicated achievements in declarative knowledge about SD, Dale and Newman [3] and Barth and Burandt [23] identified the need for the application of knowledge in practice and process knowledge. Meyer [2] reported a weak effect of higher education on SD behavior. Kollmuss and Agyeman [24] indicated a divide between knowledge, awareness, and behavior, and Salonen and Åhlberg [25] discussed a gap between attitudes of the importance of SD and its actual implementation. Many higher education programs are designed to influence values and attitudes, but there is not a direct causal link between attitude change and behavior [26]. In higher education, there is a need for educating for behavioral change [25]. Ballantyne and Packer [27] discussed the role of informal learning and lifelong learning with free-choice learning experience for supporting SD behavior or SD behavior intention.

Our study focuses on awareness, behavioral intention, and lifestyle. Awareness is defined as "concern about and well-informed interest in a particular situation or development" [28]. Fishbein [29] noted that people do not usually need to make decisions, but rather consider how they intend to behave [17]. He examined behavioral intention as a predictor of actual behavior, and found that several contextual and personal factors affect whether the behavior is aligned with attitudes and behavioral intention [26]. Meta-analysis has indicated that in SDE, behavioral intention has a small to medium effect on behavior [26,30]. Bamberg and Moser [31] argue that attitudes influence behavior indirectly via behavioral intention They show that the mediating role of behavior intention for psycho-social variables on pro-environmental behavior [31]. Within our study, lifestyle is defined as a "distinctive [and] hence recognizable mode of living" [32] (p. 28) as social practice.

In order to overcome the gap between awareness and behavior, higher education instructional design for SD should address all domains of learning [21], including the cognitive, socio-emotional, psychomotor [33], and affective [34] domains. Instructional design in higher education is relying on outcome-based curriculum with taxonomies of learning outcomes; however, critics claim that they need to be considered with a coercion to the knowledge they are applicable for [35]. In the past, the outcome-oriented curriculum in higher education has not adequately addressed the affective domain of learning; currently, authors are considering approaches for SDE that integrate affective learning outcomes [17,21]. Carew and Mitchell [36] are introducing SDE, the Structure of the Observed Learning Outcome (referred to as the SOLO taxonomy of learning outcomes) [37], which could provide a framework for the transition from the uni-structural and multi-structural (unrelated aspects) to the relational (understanding relations) and extended abstract (applying knowledge integrating multi-structural and relational). The critics argue that the SOLO taxonomy refers to vertical knowledge structures, but does not sufficiently address horizontal knowledge structures, especially when applied for higher-level outcomes that require an accumulation of learning [35]. In SDE, the transition was made from a problem-solving approach to understanding complex systems in an interdisciplinary and transdisciplinary approach [3]. This requires instructional design as indicated by Kahn across disciplines, as well as relations, reflexivity, and agency on the horizontal and vertical levels of knowledge structures [35]. The UNECE Strategy for SDE's [38] main aim is to encourage countries to integrate ESD into education systems. It covers key SD issues: poverty alleviation, citizenship, peace, ethics, responsibility in local and global contexts, democracy and governance, justice, security, 
human rights, health, gender equity, cultural diversity, rural and urban development, economy, production and consumption patterns, corporate responsibility, environmental protection, natural resource management, and biological and landscape diversity. As a specific example, we examine how Slovenian students perceive integrating SD various dimensions into the curriculum, and their personal relevance. We consider students' perception of SD issues within the other personal and academic predictors that, along with digital predictors, contribute to SD awareness, SD behavioral intention, and sustainable lifestyles.

\subsection{Learning as Boundary Crossing Connecting Social Practices}

In our research, we focused on authentic learning contexts that facilitate meaningful and contextualized learning for higher-order outcomes, and how students perceive learning context. Authentic learning refers to the construction of knowledge in real-life contexts to solve real-life problems and projects [39]. Filho et al. [40] argued for the integration of personal and professional context in a curriculum, and Mintz and Tal [21] highlighted the need for designing learning outcomes that connect the three spheres of life: private, civic, and professional. The educational change for sustainability in higher education requires a holistic approach whereby institutional or organizational change takes the form of a whole-system approach [5]. According to Mader's [4] framework, there are five components required for a transition to sustainability: leadership and vision (administration, transactional leadership, transformational leadership); social networks (information network, knowledge network, innovation network); participation (decision influencing, consultation, information); education and learning; and research (disciplinary, interdisciplinary, transdisciplinary).

Dlouha et al.'s [41] recent study of Central European countries, including Slovenia, examined the critical factors for a sustainable transition. They identified a gap between policy documents, formal curriculum content, and university practices in research and education, and universities' organizational culture and leadership. In their hierarchical overview of transition factors, universities are mainly at the initial stage, providing environmental education and individual initiatives and networking, and slowly entering the next step of understanding of SD through dialogue with stakeholders. The more advanced levels of transdisciplinary and related SD competencies are not sufficiently developed. For example, Dlouha et al. [41] identified the misunderstanding of the concept of SD at advanced levels, and found that it was based on a lack of transdisciplinary approaches, the involvement of stakeholders, and multi-stakeholder initiatives as the main obstacles to using competence-oriented teaching. They determined that the economic issues are not connected to the environmental ones. Similarly, Thomas [16] concluded that the environmental and economic issues of sustainable education are widely separated. This is mostly caused by disciplinary-based curricula where sustainability issues are present in a decontextualized and non-integrated way (that is not interdisciplinary), and are not supported by a whole-system approach.

We apply learning as boundary crossing in order to address the requirement for connecting all of the spheres of life: civic, professional, and private, and the elements of the whole-system approach. We lean on the framework of Akkerman and Bakker [42] (p. 155), who used the notion of boundary crossing to discuss learning between the different social systems of school and work, arguing for a relational rather than a "transfer" approach. The concept of the transfer in cognitive theories refers to the use of knowledge or skills in new situations or in new ways. There is a set of conditions for transfer of knowledge and skills in a learning process, and for the transfer of knowledge and skills in new situations [43]. Instead of seeing transitioning from school to work as moving between contexts with a transfer of knowledge and skills, and looking for similarity between practices, Akkerman and Bakker supported learning based on relating those different practices in the boundary area [42]. In this socio-cultural view, the learning occurs in identifying the intersections between the dissimilar contexts on either side of the boundary, and relating them productively. The term "boundary crossing" captures learning that emerges in the boundaries-merging activity systems of diverse settings [44]. 
Akkerman and Bakker [42] focused on processes and the academic-professional boundary as a part of the academic context (see Section 1.4). However, since education for SD needs to be based on students' needs and characteristics, it is important to take into account the context of the students' lifeworld [15]. We expand the notion of boundary crossing to include the academic-lifestyle boundary. We also discuss how the digital practices of students' lived experiences contribute to academic engagement [45].

We discuss the transition from teaching and learning as a didactic process to learning as boundary crossing (Figure 1).

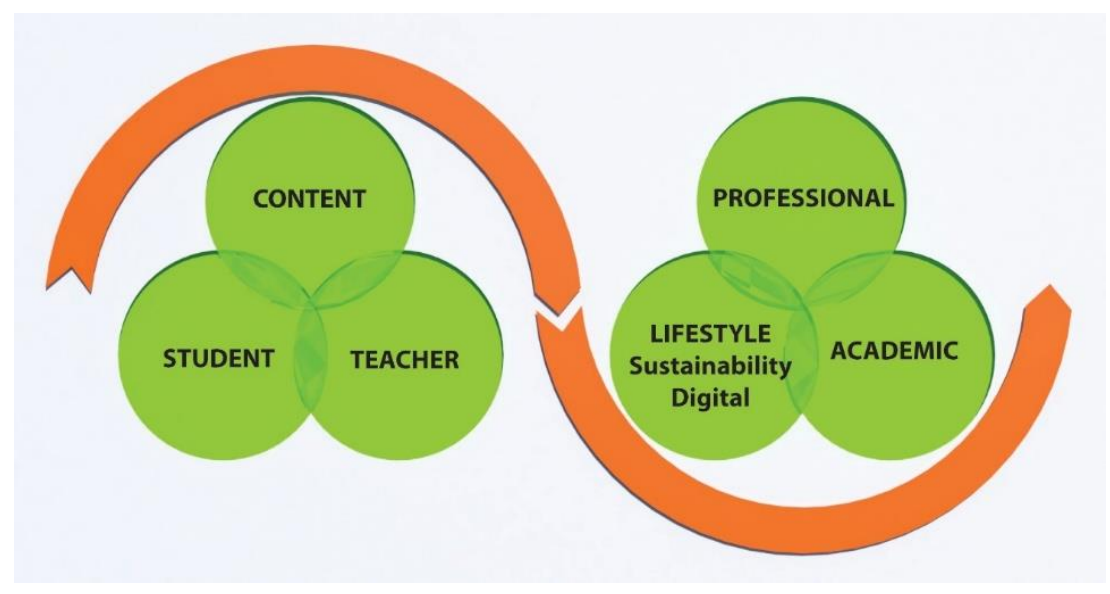

Figure 1. Achieving higher-order learning outcomes by transiting from understanding learning as a didactic process to learning as boundary crossing.

The traditional understanding of the instructive process uses a triangle to represent the interaction between teacher, student, and learning content [46]. Learning as boundary crossing sees students engaging in meaningful learning on the boundary between academic, professional, and lifestyle contexts (namely sustainable lifestyle context and digital practices). Therefore, we discuss learning in social practices captured in the SD lifestyle, within the academic factors that are utilized in teaching methods supporting authentic learning. As specific factors, digital practices are examined, which saturate students' lifeworld and are essential practices in academic and professional contexts.

\subsection{Digital Practices Providing Authenticity; Connecting Formal and Informal Learning}

Informal learning makes essential contributions to learning in professional contexts; the application of workplace learning [47] involves authentic learning about solving real-life problems [39] for the adoption of innovations [48] and learning in digital environments [49]. It also has excellent potential for SD in the personal sphere [21]. Digital technologies saturate students' lives and offer opportunities for connecting formal learning to students' lifeworld social practices. We see digital practices taking the role of boundary crosser and supporting learning through connecting social practices in personal, academic, and professional spheres (Figure 2). Digital practices combine formal and informal learning [49], and contribute to authentic learning. Authentic learning connects to social practice contexts [50], the context of authentic professional practices, and authentic lifeworld practices. Newmann [51] et al. set standards for authentic learning that included pursuing high intellectual outcomes and discouraged teaching techniques or skills with assessments that transcended beyond school [51]. Authentic learning takes place in a contextualized learning environment offering real-life complexity in the interactions between learner, task, and environment [52]. The assignment provides authenticity within the learning content and teaching methods. Baeten et al. [53] saw the student-centered teaching methods that are connected with authentic learning as having three features: active engagement, teacher as facilitator or coach, and authentic assignments. 


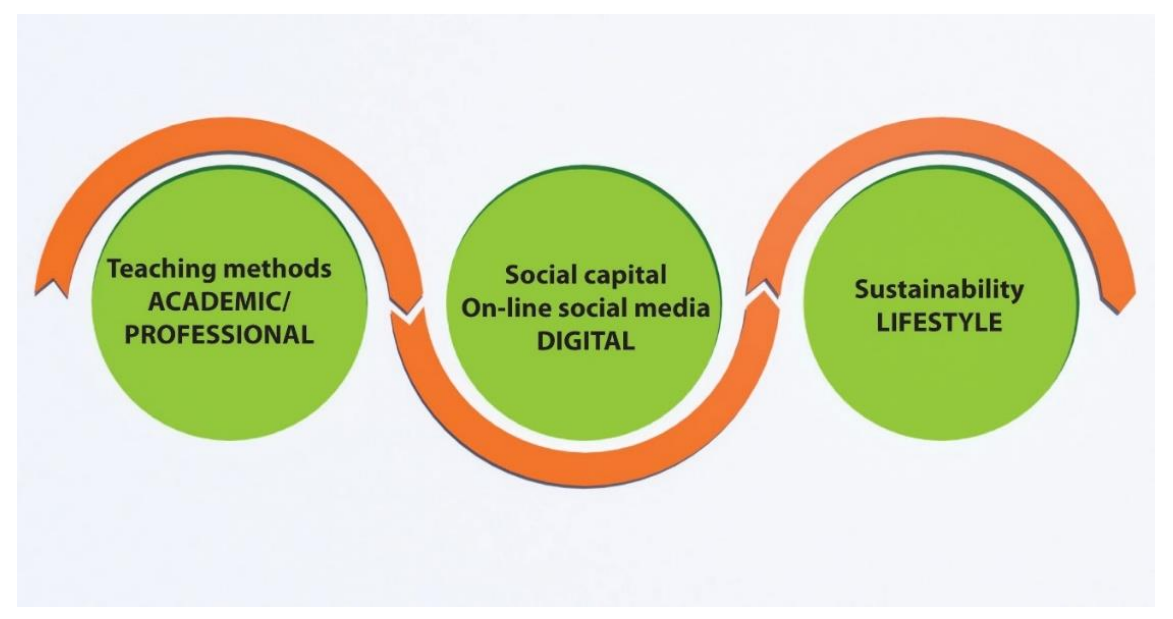

Figure 2. Connecting formal and informal learning for sustainability and the digital practices as boundary crosser.

Holdsworth and Hegarty [15] discussed higher education instructional design in urban planning, reporting that authentic learner-centered approaches are rare in higher education. Disciplinary-based higher education curricula that decontextualize are significant obstacles to SD literacy [3]. The teaching methods that could reduce decontextualization support authentic learning. Project-based learning is one such method, integrating multidimensional SD by learning in a context of complex real-world situations, applying cross-curricular approaches, and working with relevant stakeholders and into the broader society [40]. Other methods that could support higher-order learning outcomes include self-directed learning [23], collaborative learning [23], problem-based learning [16,23], experiential learning [54], and in-service learning [14].

Young people's day-to-day practices are saturated with networking in digital spaces [55]. Among the digital practices in sustainable development education, social media is discussed as having the potential to build social capital through the process and structures of relationships, which influence their activities and resources [56,57] and support bottom-up collaboration and user-created content [58]. Online social media support pedagogical transformation "where the community is the curriculum rather than understanding or accessing curriculum" [59], and as a strategic networking tool [60], foster boundary crossing between academic, professional, and personal contexts.

The local biophysical and social spaces are connected to the global contexts [8], and online social media are co-establishing it. Social networks have been recognized as an essential dimension in the higher education whole-system approach for SDE [4], and as social capital supporting sustainability integration in higher education [6]. Social capital as a parameter for SD in higher education has four dimensions: social trust or peer effect, which supports lifestyle change; institutional trust, or gaining support from the campus community and society; social networks with formal and informal connections; and social norms supporting daily life and culture [6]. Chiong et al. [6] also stressed the lack of study in the area of social capital associated with SD awareness as an intrinsic interest driving behavior change. In our study, we examined digital practices as the third block of predictors, looking at students' Information and Communications Technology (ICT) use in their free time and academic learning, ICT use in teaching, online social media as a source for education for SD, and online social media as an SD behavior promoter. The digital social practices are highlighted.

\subsection{The Objectives of the Study}

Sustainable development is a multidimensional issue. However, research findings report a divide between students' awareness and behavior. It is identified that study programs are designed for awareness outcomes, rather than for behavioral outcomes [26]. For higher learning outcomes manifested in SD behaviors, we argue for a model based on an understanding of learning as boundary 
crossing. Based on this model, learning for sustainable development occurs in relating social practices, as well as the lifeworlds and lifestyles of academics, professionals, and students. To inform teachers' approaches to teaching, who are an important driver of institutional change, we have to identify students' perceptions of learning contexts, teaching methods, and their learning outcomes [61]. Therefore, the objectives of this study are to examine to what extent students' perceptions of personal, academic, and digital factors predict students' SD awareness, SD behavioral intention, and SD lifestyle. Using independent variables, we examined students' perceptions of SD issues and discuss how its multidimensionality was integrated into curriculum and students' personal relevance. Further, within personal, academic, and digital predictors, we examine students' perception of learning in social practices within the personal factors captured in the SD lifestyle, as well as within the academic factors captured in perceived teaching methods. As a special block of factors, digital practices are examined, which saturate students' lifeworlds and capture social practices in students' ICT use, teacher ICT use of pervasive social media, and the perception of online social media as a source of SD information and a SD behavior promotor.

The hypotheses:

Hypotheses 1 (H1). There is a difference in the contribution of academic, personal, and digital predictors to SD awareness, $S D$ behavioral intention, and sustainable lifestyles.

Hypotheses 2 (H2). It is identified that courses prepare students for SD awareness, but do not sufficiently prepare them for SD behavior; we hypothesized that a significant predictor for SD behavior that could be measured as sustainable lifestyle and SD behavioral intention, is learning in social practices.

Hypotheses 3 (H3). The preferred teaching methods are predicted by learning in social practices (lifestyle, perceived teaching methods, and digital practices).

\section{Materials and Methods}

We surveyed to examine the predictors of the outcome variables by testing the formulated hypotheses.

\subsection{Participants}

We surveyed a sample of 847 Slovenian students in urban and spatial planning study programs in the academic year 2014/15 (30.70\% of the total number of 2.759 students). All of the participants were informed about the study, and had agreed to fill in the anonymous questionnaire. Probability sampling was applied by a multistage sampling by groups [62]. After removing participants with missing data, we retained a sample of $618,331(53.6 \%)$ of whom were female, and $287(46.4 \%)$ of whom were male. We surveyed students from Civil Engineering, Architecture, Spatial Urban Planning, Construction Management, Water Science and Environmental Engineering, Geodesy and Geo-information, Technical Real Estate Management, Spatial Planning, and Buildings.

\subsection{Measures}

We examined related research studies in order to conduct an in-depth review of how previous studies treated constructs. The expert assessment was conducted for content validity [63]. For final inclusion of the item, the condition was the agreement of half of all of the experts from the group. A series of five-point interval scales were applied for the self-reported items, using the following variables:

Dependent variables:

- SD awareness was examined according to Kagawa [64], who observed familiarity with the concept of sustainable development of students in different disciplines, and among them students of environmental science. According to Kagawa, the four-point scale includes: very familiar, quite familiar, quite unfamiliar, and not familiar at all. We also added neither familiar/neither 
unfamiliar. We covered a question: Are you familiar with sustainable development, and if so, to what extent? Answers were designed on a five-point scale that included: very familiar, quite familiar, neither familiar/neither unfamiliar, quite unfamiliar, and not familiar at all.

- Sustainable lifestyle was examined according to Kagawa [64], who identified the most frequently occurring categories of a sustainable lifestyle. We included in our questionnaire: saving natural resources, a way of transportation, choice of supplier, membership in a society, education, and self-sufficiency. Answers were designed on the five-point Likert scale, where five indicated "totally agree", and one indicated "totally disagree".

- SD behavioral intention referred to future actions with items designed according to Reid et al. [65], who examined the extent to which SD will be necessary in future professional work, as well as private life and academic study. Accordingly, we added in a scale of day-to-day practice and academic studies. We included in our questionnaire: "In the future, I am interested in the field of sustainable development in the course of academic studies"; "In the future, I am interested in the field of sustainable development in the context of professional work"; and "In the future, I will try to understand the concept of sustainable development better and integrate it into day-to-day activities". The answers were designed on the five-point Likert scale, from five-totally agree to one-totally disagree.

- Preferences for teaching methods for SD focused on teaching methods supporting authentic learning. They were integrated from the syllabus of participating students' study programs. We covered: problem-based learning, case study, project work, learning by inquiry, communion participation, observation, learning in a real-life context, in-service learning, and experiment. Answers were designed on a five-point Likert scale, from five-very frequently, to one-not at all.

Independent variables:

- Perceived sources for SDE information were examined according to items identified by Reid et al. [65]. Academic education was inserted for all levels of education: elementary, high school and higher education. Kagawa examined sources under two categories: formal curriculum and out of school activities [55]; in our instrument, we also added academic and non-academic activity. We included: academic study in elementary school, academic study in high school, academic study at university, friends and schoolmates, radio and television, print media, and online social media. Answers were designed on a five-point Likert scale, from five-a lot to one-not at all. The two that were most highly rated, academic study at university and online social media, were applied as independent variables.

- Perceived sources for SD behavior promotion were examined by students' rating the importance of sources for SD behavior promotion. We included: academic study in elementary school, academic study in high school, academic study at university, friends and schoolmates, radio and television, print media, and online social media. Answers were designed on a five-point scale Likert scale, from 5-totally agree to 1 -totally disagree. Among the three most highly rated-the first, academic study at university and the third, online social media-were applied as independent variables.

- Personal relevance of SD issues was examined according to United Nations Economic Commission for Europe (UNECE) issues [38]. We included: poverty alleviation, citizenship, peace, ethics, responsibility in local and global contexts, democracy and governance, justice, security, human rights, health, gender equity, cultural diversity, rural and urban development, economy, production and consumption patterns, corporate responsibility, environmental protection, natural resource management, and biological and landscape diversity. Answers were designed on a five-point Likert scale, from five-a lot to one-not at all.

- The SD issues inclusion in the curriculum was examined according to UNECE issues [38]. We included items indicated under point three. Answers were designed on a five-point Likert scale, from five- -very frequently to one-not at all. 
- Students' ICT use in their free time and for learning. We included tools and online resources. Answers were designed on a five-point Likert scale, from five-very frequently to one - not at all.

- ICT use in teaching included tools and online resources. Answers were designed on a five-point Likert scale, from five- very frequently to one-not at all.

- Students' perception of teaching methods for SD included teaching methods that support authentic learning. They were integrated from the syllabus of participating students' study programs. We included problem-based learning, a case study, project work, learning by inquiry, communion participation, observation, learning in a real-life context, in-service learning, and experiment. Answers were designed on a five-point Likert scale, from five-very frequently to one-not at all.

The predictors were examined within three blocks.

(1) Within the academic-lifestyle boundary, the personal predictors were examining students' personal contexts with the following independent variables: the personal relevance of SD issues-environmental and economic (EE), and the personal relevance of SD issues-social, SD awareness, SD behavioral intention, and sustainable lifestyle. Sustainable lifestyle is representing social practice. Due to the broad personal context in boundary-crossing learning, variable 2 (sustainable lifestyle) was also entered as a person-related predictor in models predicting SD awareness, SD behavioral intention, and preferred teaching methods. Similarly, variable one (SD awareness) was entered as a person-related predictor in models predicting sustainable lifestyle, SD behavioral intention, and preferred teaching methods.

(2) At the academic-professional boundary, academic predictors were examined. These included: the inclusion of SD issues in the curriculum - environmental and economic (EE), social, study at university as a source of SD information, and study at university as a source of SD behavior promotion. Authentic teaching methods were also included. Factor analysis indicated a latent variable; teaching methods supporting authentic learning, which connects academic and real-life professional contexts, and also represents social practices.

(3) At the academic-lifestyle boundary, the digital predictors examined the digital practices and boundary crossing between academic and digital practices. Digital practices are discussed as students' lived experiences and their contribution to academic engagement. Among digital practices, we examined student ICT use-e-books and portals; student ICT use-social network sites, video, and encyclopedia; and student ICT use-blogs, teachers' ICT use in teaching, online social media as sources of SD information, and online social media as SD behavior promoters. Apart from ICT use-e-books and portals, all of the other items represented social practices.

\subsection{Data Analysis}

Using the SPSS software program, we performed principal axis factoring to discover reliable and clear factors from a more extensive set of items in the initial questionnaire. Descriptive statistics and intercorrelations for factors and items were calculated. We used a hierarchical linear regression analysis to establish the influence of specific predictors on three outcome variables.

This section may be divided by subheadings. It should provide a concise and precise description of the experimental results, their interpretation, and the experimental conclusions that can be drawn.

\section{Results}

\subsection{Factor Analysis and Reliability Assessment}

We performed a set of factor analyses to establish clear, reliable factors for each category of variables, and discover the latent structure of the measured constructs. We performed principal axis factoring with varimax rotation whenever there were multifactor solutions. Scree plots were used to decide on the number of extracted factors, which is an appropriate method for large samples with items dropped before initial exploratory factor analysis (EFA), because of their high correlation with 
other items resulted in too low a determinant value $(<0.00001)$. Some items were dropped after the initial EFA, because of cross loading. Solutions with Kayser-Mayer-Olkin (KMO) values above 0.70, and in one case 0.65 , were applied, and items with factor loadings more than or equal to 0.40 were retained. A Cronbach's alpha higher than 0.70 indicated sufficient item reliability. In all of the cases, the retained factors had eigenvalues above the value of 1, which is consistent with Kaiser's criteria for factor retention. Factors with higher eigenvalues explained a larger proportion of variance in each EFA in comparison to other retained factors.

Results from the EFA on the items measuring sustainable lifestyle (Table 1) showed two latent factors $(\mathrm{KMO}=0.800, \alpha=0.78, \alpha=0.69)$, which are discussed underneath Table 1 .

$\mathrm{SD}$ behavioral intention (Table 2$)$ is a one-factor solution ( $\mathrm{KMO}=0.734 ; \alpha=0.88$ ).

We applied the UNECE [34] issues for items measuring the personal relevance of SD issues and the inclusion of SD issues in the curriculum (Table 3). Principal axis factoring revealed two factors for each:

- Inclusion in Curriculum-Social issues (KMO = 0.823; $\alpha=0.85)$;

- Inclusion in Curriculum-Environmental and Economic issues (KMO =0.823; $\alpha=0.81$ );

- Personal relevance-Environmental and Economic issues (KMO =0.823; $\alpha=0.81)$;

- Personal relevance-Social issues $(\mathrm{KMO}=0.823 ; \alpha=0.80)$.

An EFA of items measuring students' ICT use for learning and leisure (Table 4) identified three reliable factors $(\alpha>0.7)$. Factor 1 represents the use of e-resources, including e-books and portals, for searching for professional e-journals $(\mathrm{KMO}=0.650 ; \alpha=0.71)$. The second and the third factor covered pervasive social media. Factor 2 represents the usage of social network sites, such as for example, YouTube, Facebook, and Wikipedia $(\mathrm{KMO}=0.650 ; \alpha=0.71)$. In the third factor, the use of (micro) blogging tools was shown as a separate construct in EFA $(\mathrm{KMO}=0.650 ; \alpha=0.70)$.

Items measuring digital practices in teaching (Table 5) showed one factor: teacher ICT use $(\mathrm{KMO}=0.777 ; \alpha=0.75)$.

Items measuring the use of teaching methods for SD (Table 6) were analyzed with EFA. Two factors were identified, with the first corresponding to perceived teaching methods by students $(\mathrm{KMO}=0.912$; $\alpha=0.91$ ) and the second corresponding to items measuring preferred teaching methods, which revealed one factor $(\mathrm{KMO}=877 ; \alpha=0.88)$.

Table 1. Results of exploratory factor analysis (EFA) for sustainable development (SD) lifestyle.

\begin{tabular}{|c|c|c|c|c|}
\hline Factor & Items & 1 & 2 & $\alpha$ \\
\hline \multirow{5}{*}{ Sustainable lifestyle } & ... Choice of supplier (organic, local products, recycled, green energy ...). & 0.676 & 0.303 & \\
\hline & ... Membership in a 'green' group, society, or organization. & 0.668 & & \\
\hline & ... Self-sufficiency (solar panels, composting, gardening ...). & 0.662 & 0.307 & \\
\hline & ... By educating oneself and others. & 0.620 & 0.256 & \\
\hline & $\begin{array}{l}\text { Eigenvalue }=2.96 \\
\% \text { Variance }=49.41\end{array}$ & & & 0.78 \\
\hline \multirow[t]{3}{*}{$\begin{array}{c}\text { Day-to-day sustainable } \\
\text { behavior }\end{array}$} & Natural resource-saving (water, electricity recycling ... ). & 0.261 & 0.902 & \\
\hline & Way of transportation (walking, cycling, public transport ... ). & 0.154 & 0.497 & \\
\hline & $\begin{array}{l}\text { Eigenvalue }=1.05 \\
\% \text { Variance }=17.49\end{array}$ & & & 0.65 \\
\hline
\end{tabular}

Note: Extraction method: principal axis factoring. Rotation method: Varimax with Kaiser normalization. $\mathrm{KMO}=0.800$.

As presented in Table 1, an EFA conducted on items related to an SD lifestyle revealed two latent dimensions. The first factor explained a larger part of the variance $(49.41 \%)$. We named the first factor a 'sustainable lifestyle' factor, because it included items that in our opinion represent more distinctive modes of living. Individuals with a higher score on the first factor tend to take actions, reflecting a lifestyle of a greater awareness of the sustainability issues. Factor includes items that describe a 
more active approach toward sustainability issues, whether on the personal (choice of a supplier, self-sufficiency) or on the social level (membership in an organization, educating others).

Items from the second factor describe day-to-day sustainable behavior (natural resource saving, choosing ways of transportation), and were omitted from further analysis because of their low reliability $(\alpha<0.7)$. The second factor explained an additional $17.49 \%$ of the variance.

However, factor analysis showed two latent factors of SD lifestyle, explaining the nature of the $\mathrm{SD}$ lifestyle is beyond the scope of this article.

Table 2. Students' sustainable development behavioral intentions.

\begin{tabular}{|c|c|c|c|}
\hline Factor & Items & 1 & $\alpha$ \\
\hline \multirow[t]{4}{*}{$\begin{array}{l}\text { The sustainable development } \\
\text { behavioral intention }\end{array}$} & $\begin{array}{l}\text { In the future, I am interested in the field of sustainable } \\
\text { development in the course of academic studies. }\end{array}$ & 0.889 & \\
\hline & $\begin{array}{l}\text { In the future, I am interested in the field of sustainable } \\
\text { development in the context of professional work. }\end{array}$ & 0.883 & \\
\hline & $\begin{array}{l}\text { In the future, I will try to understand the concept of } \\
\text { sustainable development better and integrate it into } \\
\text { day-to-day activities. }\end{array}$ & 0.779 & \\
\hline & $\begin{array}{l}\text { Eigenvalue }=2.44 \\
\% \text { Variance }=81.49\end{array}$ & & 0.88 \\
\hline
\end{tabular}

As seen in Table 2, sustainable development behavioral intention is a one-factor solution, showing the homogeneity of the construct. A three-item factor explains $81.49 \%$ of the variance of the SD behavioral intention.

In Table 3, a four-factor solution is presented for items measuring the personal relevance of issues for sustainable development and the inclusion of these issues in the curriculum. From the initial version of issues [34], 10 items were dismissed because of reasons mentioned previously.

Table 3. Results of EFA for issues of sustainable development.

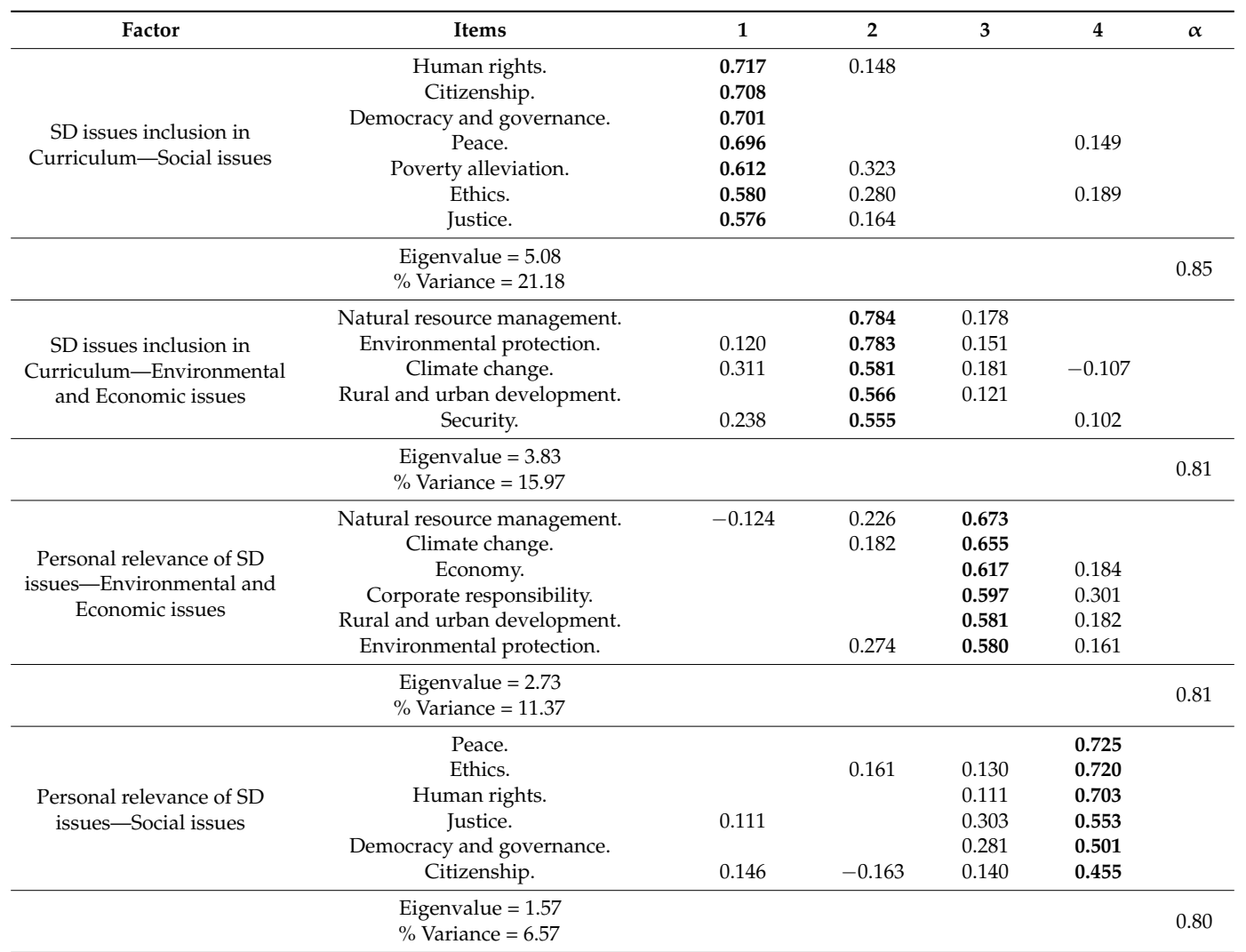

Note: Loadings $<0.10$ have been omitted. Extraction method: principal axis factoring. Rotation method: Varimax with Kaiser normalization. $\mathrm{KMO}=0.823$. 
As seen in Table 3, the principal axis factoring of remaining items revealed two factors each for personal relevance and inclusion in the curriculum. The nature of the latent factors could be described as covering 'social' (factor 1,4) and 'environmental and economic' issues (factors 2, 3). Two factors, reflecting SD issues, that were covered with the curriculum explained together $37.15 \%$ of variance, and the personal relevance of SD issues explained an additional $17.94 \%$.

An EFA of items measuring students' ICT use for learning and leisure showed three reliable factors $(\alpha>0.7)$ (Table 4). The same ICT, regardless if it was used for learning or leisure, loaded on the same factor, indicating high correlations of specific ICT usage for both purposes. An item 'Leisure-Web encyclopedia (e.g., Wikipedia)' was omitted because of cross loading on different factors.

Table 4. Results for EFA for students' ICT use.

\begin{tabular}{|c|c|c|c|c|c|}
\hline Factor & Items & 1 & 2 & 3 & $\alpha$ \\
\hline \multirow[t]{5}{*}{$\begin{array}{l}\text { Student ICT use-e-books, } \\
\text { portals }\end{array}$} & Free time-Electronic books. & 0.685 & 0.207 & & \\
\hline & Learning_Electronic books. & 0.671 & 0.165 & 0.174 & \\
\hline & $\begin{array}{l}\text { Free time-Search Portal for scientific and } \\
\text { professional journals (e.g., Mrežnik—NUK). }\end{array}$ & 0.551 & -0.129 & 0.141 & \\
\hline & $\begin{array}{l}\text { Learning-Search Portal for scientific and } \\
\text { professional journals (e.g., Mrežnik—NUK). }\end{array}$ & 0.524 & & & \\
\hline & $\begin{array}{c}\text { Eigenvalue }=2.92 \\
\% \text { Variance }=22.46\end{array}$ & & & & 0.71 \\
\hline \multirow{6}{*}{$\begin{array}{l}\text { Student ICT use-social } \\
\text { network sites, video, } \\
\text { encyclopedia }\end{array}$} & Learning_Social network sites (e.g., Facebook). & -0.102 & 0.667 & & \\
\hline & Free time—-Social network sites (e.g., Facebook). & & 0.608 & & \\
\hline & Free time-Video (e.g., YouTube). & 0.193 & 0.566 & & \\
\hline & Learning_Video (e.g., YouTube). & -0.140 & 0.566 & & \\
\hline & Learning_Online Encyclopedia (e.g., Wikipedia). & 0.150 & 0.459 & & \\
\hline & $\begin{array}{c}\text { Eigenvalue }=2.32 \\
\% \text { Variance }=17.86\end{array}$ & & & & 0.71 \\
\hline \multirow[t]{5}{*}{ Student ICT use—blogs } & Free time-Microblog (e.g., Twitter). & & & 0.744 & \\
\hline & Learning_Microblog (e.g., Twitter). & & & 0.704 & \\
\hline & Free time-Weblog. & 0.321 & & 0.491 & \\
\hline & Learning_Weblog. & 0.242 & & 0.444 & \\
\hline & $\begin{array}{l}\text { Eigenvalue }=1.58 \\
\% \text { Variance }=12.19\end{array}$ & & & & 0.70 \\
\hline
\end{tabular}

Note: Loadings $<0.10$ have been omitted. Extraction method: principal axis factoring. Rotation method: Varimax with Kaiser normalization. $\mathrm{KMO}=0.650$.

A three-factor solution of students' ICT use is presented in Table 4. Factor 1 represents the usage of e-resources (e-books and portals for searching professional e-journals), explaining $22.46 \%$ of variance. Factors 2 and 3 represent pervasive social media. Factor 2 represents the usage of social network sites (e.g., YouTube, Facebook, and Wikipedia). It explains $17.86 \%$ of variance of students' ICT use. In factor 3, the usage of (micro)blogging tools was shown as a separate construct in EFA (Factor 3 in Table 4), explaining an additional $12.19 \%$ of variance.

Items measuring teacher' digital practices in teaching showed one factor, which is presented in Table 5. 
Table 5. Results of EFA for Teacher ICT use in teaching.

\begin{tabular}{|c|c|c|c|}
\hline & Items & 1 & $\alpha$ \\
\hline \multirow[t]{8}{*}{ Teacher ICT Use } & Online encyclopedia (e.g., Wikipedia). & 0.712 & \\
\hline & Search portal for scientific and professional journals (e.g., Mrežnik-NUK). & 0.633 & \\
\hline & Microblog (e.g., Twitter). & 0.579 & \\
\hline & Weblog. & 0.541 & \\
\hline & Social network sites (e.g., Facebook). & 0.535 & \\
\hline & Electronic books. & 0.535 & \\
\hline & Video (e.g., YouTube). & 0.430 & \\
\hline & $\begin{array}{c}\text { Eigenvalue }=2.94 \\
\% \text { Variance }=42.04\end{array}$ & & 0.75 \\
\hline
\end{tabular}

Note: Extraction method: principal axis factoring. $\mathrm{KMO}=0.777$.

In Table 5 , it is seen that retained factor explained $42.04 \%$ of teacher ICT use.

Items measuring actual and preferred authentic teaching methods were analyzed with EFA. As seen in Table 6, items were loaded on two factors (Table 7). The first factor corresponded to perceived teaching methods, and items on the second factor described preferred authentic teaching methods.

Table 6. Results of EFA for teaching methods.

\begin{tabular}{|c|c|c|c|c|}
\hline Factor & Items & 1 & 2 & $\alpha$ \\
\hline \multirow{11}{*}{$\begin{array}{l}\text { Students' perception of } \\
\text { teaching methods }\end{array}$} & Perceived-Learning by inquiry. & 0.725 & 0.145 & \\
\hline & Perceived-Learning to solve existing real-life problems. & 0.723 & 0.139 & \\
\hline & Perceived-Structured observation. & 0.711 & 0.152 & \\
\hline & Perceived-Learning by community participation. & 0.706 & 0.159 & \\
\hline & Perceived-Learning out of classroom real-life context. & 0.682 & & \\
\hline & Perceived-Project work. & 0.664 & 0.230 & \\
\hline & Perceived-In-service learning/practical training. & 0.661 & & \\
\hline & Perceived-Fieldwork. & 0.618 & & \\
\hline & Perceived-Experiment. & 0.587 & 0.143 & \\
\hline & Perceived-Excursions. & 0.553 & 0.143 & \\
\hline & Perceived-Learning with a case study. & 0.491 & 0.246 & \\
\hline & $\begin{array}{c}\text { Eigenvalue }=7.35 \\
\% \text { Variance }=33.42\end{array}$ & & & 0.89 \\
\hline \multirow{12}{*}{$\begin{array}{l}\text { Preferred teaching } \\
\text { methods }\end{array}$} & Preferred-Experiment. & & 0.710 & \\
\hline & Preferred-In-service learning/practical training. & & 0.706 & \\
\hline & Preferred-Learning to solve existing real-life problems. & 0.146 & 0.663 & \\
\hline & Preferred-Learning by inquiry. & 0.188 & 0.659 & \\
\hline & Preferred-Project-based learning. & 0.258 & 0.651 & \\
\hline & Preferred-Fieldwork. & & 0.648 & \\
\hline & Preferred-Learning out of classroom real-life context. & 0.160 & 0.641 & \\
\hline & Preferred-Learning by community participation. & 0.198 & 0.620 & \\
\hline & Preferred-Excursions. & & 0.584 & \\
\hline & Preferred-Learning with a case study. & & 0.566 & \\
\hline & Preferred-Structured observation. & 0.322 & 0.540 & \\
\hline & $\begin{array}{c}\text { Eigenvalue }=3.44 \\
\% \text { Variance }=15.65\end{array}$ & & & 0.88 \\
\hline
\end{tabular}

Note: Extraction method: principal axis factoring. Rotation method: Varimax with Kaiser normalization. $\mathrm{KMO}=0.877$.

The students' perception of authentic teaching methods use explained $33.45 \%$ of variance in teaching methods, and students' preference for authentic teaching methods use explained an additional $15.65 \%$ of variance of teaching methods.

\subsection{Descriptive Statistics and Correlational Analysis}

The descriptive statistics $(M, \mathrm{SD})$ for the average scores $(N=617)$ on each construct and the Pearson product moment coefficients for all of the possible pairings are presented in Table 7. Lowest means are associated with items measuring the usage of specific ICT tools by teachers $(M=1.79)$ and students: blogs $(M=1.41)$, e-books, and portals $(M=2.15)$. Highest means are for items measuring the personal relevance of environmental and economic issues $(M=4.28)$ and perceiving study as a sustainable behavior promoter $(M=4.08)$. Students perceive environmental and economic issues to be more relevant for SD than social issues. They also recognize social matters to be included less frequently in the curriculum than environmental and economic matters. Among the outcome variables, 
the highest mean is associated with the behavioral intention $(M=3.52)$ and the lowest is associated with sustainable lifestyle $(M=3.01)$. The average scores' mean is much higher for preferred $(M=3.77)$ than perceived teaching methods supporting authentic learning $(M=2.74)$. Higher average scores indicate that students consider study as a more important source of information for SD, and as a larger promoter of sustainable behavior than social media. Although social media had a lower average, it was also a significant predictor.

Although the numerous significant small correlations indicate that the items are conceptually related, they appear to be statistically independent measures. There are no significant negative correlations between the variables. Correlations between variables are weak (0.08 to 0.29$)$ to moderate (0.31 to 0.44$)$. The highest correlations are between awareness and study as a source of information $(r=0.44)$, and study as a source of information and behavior promotion $(r=0.43)$. Among the dependent variables, preferred teaching methods supporting authentic learning have the most significant correlations with other variables.

\subsection{Hierarchical Linear Regression Analyses}

Four hierarchical linear regressions were performed to examine the importance of personal, academic, and digital predictors in explaining the outcome variables of SD behavioral intention, SD awareness, sustainable lifestyle, and preferred teaching methods. In all of the analyses, the variables were entered in blocks. The blocks contained predictors related to the person, academic study, and students' and teachers' digital practices, respectively. In Tables 8-11, results are presented for a set of hierarchical regression analysis.

Concerning SD awareness, Table 8 shows that academic predictors account for a substantial part $(17.3 \%)$ of the variance, with the study providing an essential source of information and promotion of behavior. Significant academic predictors of SD awareness are: seeing study as a source of information ( $\beta=0.363$ ) and seeing study as a promoter of behavior $(\beta=0.089)$. Personal predictors add $9.4 \%$, with the relevance of environmental and economic SD issues being a significant predictor $(\beta=0.206)$. Adding digital factors did not significantly improve the model.

Personal, academic, and digital factors were significant predictors of SD behavioral intention (see Table 9). Personal variables made the highest contribution (20.7\%). Among them, sustainable lifestyle ( $\beta=0.238$ ) and SD awareness $(\beta=0.140)$ were the most important, but the personal relevance of all of the SD issues also contributed $(\beta=0.108 ; \beta=0.080$ ). Academic factors explained an additional $7.8 \%$, with seeing the study as a source of behavior promotion being the most important $(\beta=0.197)$. In step 3 , perceived teaching methods also showed a relatively small but significant regression coefficient ( $\beta=0.093)$. Digital practices contributed marginally $(2.3 \%)$, while seeing social media as a source of information was a significant predictor $(\beta=0.135)$. Teachers' ICT usage shows a significant negative correlation coefficient ( $\beta=-0.096$ ).

Only $14.5 \%$ of the variance in sustainable lifestyle can be explained using the predictors in our model (Table 10), with digital practices and academic factors explaining very similar amounts of variance (5.9\% and 5.7\%, respectively). Among digital practices, students' use of e-resources ( $\beta=0.124)$, seeing social media as a source of information $(\beta=0.107)$ and behavior promotion $(\beta=0.094)$, and teachers' use of ICT $(\beta=0.092)$ are important predictors. The data on the effect of academic factors is inconclusive. The inclusion of social issues in curricula $(\beta=0.098)$ and using teaching methods ( $\beta=0.097$ ) are significant positive predictors, but seeing the study as the source of behavior promotion negatively predicts lifestyle $(\beta=-0.109)$. Person-related predictors in our model showed a marginal influence (2.0\% of explained variance), with the personal relevance of social issues being the most important predictor $(\beta=0.113)$.

Academic factors account for $13.6 \%$ and personal factors account for $12.8 \%$ of the variance of preferred teaching methods (Table 11). Perceived teaching methods are the most significant predictor ( $\beta=0.297)$, followed by sustainable lifestyle $(\beta=0.192)$, and study as a source of behavior promotion ( $\beta=0.120)$. Digital factors add $2.5 \%$, with predictors related to social media. 
Table 7. Intercorrelations between measures-Pearson's r.

\begin{tabular}{|c|c|c|c|c|c|c|c|c|c|c|c|c|c|c|c|c|c|c|c|}
\hline & M & SD & 1 & 2 & 3 & 4 & 5 & 6 & 7 & 8 & 9 & 10 & 11 & 12 & 13 & 14 & 15 & 16 & 17 \\
\hline (1) Personal relevance of SD issues-EE & 4.28 & 0.64 & 1.00 & & & & & & & & & & & & & & & & \\
\hline (2) Personal relevance of SD issues-Social & 3.75 & 0.77 & 0.397 & 1.00 & & & & & & & & & & & & & & & \\
\hline (3) SD awareness & 3.37 & 1.06 & 0.307 & 0.106 & 1.00 & & & & & & & & & & & & & & \\
\hline (4) Sustainable lifestyle & 3.01 & 0.97 & 0.069 & 0.168 & 0.023 & 1.00 & & & & & & & & & & & & & \\
\hline (5) SD issues' inclusion in Curriculum-EE & 3.51 & 0.88 & 0.264 & 0.054 & 0.210 & 0.122 & 1.00 & & & & & & & & & & & & \\
\hline (6) SD issues' inclusion in Curriculum-Social & 2.39 & 0.80 & -0.007 & 0.137 & 0.004 & 0.199 & 0.343 & 1.00 & & & & & & & & & & & \\
\hline (7) Study at university-Information & 3.35 & 1.17 & 0.172 & -0.006 & 0.442 & 0.023 & 0.397 & 0.191 & 1.00 & & & & & & & & & & \\
\hline (8) Study at university—-Behavior promotion & 4.08 & 0.98 & 0.258 & 0.097 & 0.331 & -0.022 & 0.253 & -0.042 & 0.434 & 1.00 & & & & & & & & & \\
\hline (9) Perceived teaching methods & 2.74 & 0.86 & 0.051 & -0.009 & 0.093 & 0.180 & 0.257 & 0.249 & 0.205 & 0.112 & 1.00 & & & & & & & & \\
\hline (10) Student ICT use-E-books, portals & 2.15 & 0.93 & 0.086 & 0.187 & 0.137 & 0.242 & 0.139 & 0.198 & 0.182 & 0.189 & 0.272 & 1.00 & & & & & & & \\
\hline (11) Student ICT use-Blogs & 1.41 & 0.64 & -0.055 & 0.062 & 0.041 & 0.138 & 0.030 & 0.155 & 0.032 & -0.018 & 0.186 & 0.306 & 1.00 & & & & & & \\
\hline (12) Student ICT use-Social network sites, video, encyclopedia & 3.67 & 0.82 & 0.070 & 0.033 & 0.006 & 0.061 & 0.178 & 0.119 & 0.075 & 0.063 & 0.159 & 0.118 & 0.020 & 1.00 & & & & & \\
\hline (13) Teacher ICT use & 1.79 & 0.68 & 0.024 & 0.027 & 0.121 & 0.211 & 0.098 & 0.262 & 0.208 & 0.077 & 0.287 & 0.421 & 0.413 & 0.152 & 1.00 & & & & \\
\hline (14) Social media-Information & 2.99 & 1.17 & 0.109 & 0.084 & 0.205 & 0.170 & 0.231 & 0.096 & 0.378 & 0.211 & 0.088 & 0.190 & 0.140 & 0.149 & 0.208 & 1.00 & & & \\
\hline (15) Social media-Behavior promotion & 3.48 & 1.13 & 0.164 & 0.114 & 0.188 & 0.146 & 0.156 & -0.028 & 0.153 & 0.400 & 0.079 & 0.206 & 0.068 & 0.101 & 0.130 & 0.415 & 1.00 & & \\
\hline (16) SD behavioral intention & 3.52 & 1.06 & 0.278 & 0.217 & 0.314 & 0.276 & 0.233 & 0.031 & 0.292 & 0.352 & 0.165 & 0.157 & 0.013 & 0.045 & 0.043 & 0.287 & 0.255 & 1.00 & \\
\hline (17) Preferred teaching methods & 3.77 & 0.80 & 0.216 & 0.177 & 0.112 & 0.289 & 0.265 & 0.217 & 0.189 & 0.213 & 0.375 & 0.190 & 0.026 & 0.186 & 0.103 & 0.215 & 0.185 & 0.363 & 1.00 \\
\hline
\end{tabular}

EE-Environmental and economic; SD—Sustainable development. Significant values $p<0.05$ are shown in bold. 
Table 8. Regression analyses of predictors for SD awareness.

\begin{tabular}{|c|c|c|c|c|c|c|c|c|c|c|}
\hline \multirow[b]{2}{*}{ Step } & \multirow[b]{2}{*}{ Variables entered } & \multicolumn{3}{|c|}{ Step 1} & \multicolumn{3}{|c|}{ Step 2} & \multicolumn{3}{|c|}{ Step 3} \\
\hline & & $\mathrm{b}$ & SE & $\beta$ & $\mathrm{b}$ & SE & $\beta$ & $\mathrm{b}$ & SE & $\beta$ \\
\hline & Constant & 1.238 & 0.306 & & 0.350 & 0.313 & & 0.395 & 0.342 & \\
\hline \multirow[t]{3}{*}{1 Personal } & $\begin{array}{l}\text { Personal relevance of SD } \\
\text { issues-EE }\end{array}$ & 0.086 & 0.011 & 0.314 & 0.055 & 0.011 & 0.202 & 0.056 & 0.011 & 0.206 \\
\hline & $\begin{array}{l}\text { Personal relevance of SD } \\
\text { issues-Social }\end{array}$ & -0.005 & 0.010 & -0.020 & 0.005 & 0.009 & 0.024 & 0.004 & 0.009 & 0.017 \\
\hline & Sustainable lifestyle & 0.001 & 0.011 & 0.005 & 0.003 & 0.010 & 0.010 & -0.002 & 0.010 & -0.008 \\
\hline \multirow[t]{5}{*}{2 Academic } & $\begin{array}{l}\text { SD issues' inclusion in } \\
\text { curriculum-EE }\end{array}$ & & & & 0.001 & 0.010 & 0.002 & 0.002 & 0.010 & 0.010 \\
\hline & $\begin{array}{l}\text { SD issues' inclusion in the } \\
\text { curriculum-Social }\end{array}$ & & & & -0.013 & 0.007 & -0.068 & -0.014 & 0.008 & -0.074 \\
\hline & $\begin{array}{l}\text { Study at } \\
\text { university-Information }\end{array}$ & & & & 0.334 & 0.037 & 0.371 & 0.327 & 0.040 & 0.363 \\
\hline & $\begin{array}{c}\text { Study at university-Behavior } \\
\text { promotion }\end{array}$ & & & & 0.119 & 0.043 & 0.111 & 0.096 & 0.047 & 0.089 \\
\hline & Perceived teaching methods & & & & 0.001 & 0.004 & 0.009 & 0.000 & 0.004 & -0.002 \\
\hline \multirow[t]{6}{*}{3 Digital } & $\begin{array}{l}\text { Student ICT use-E-books, } \\
\text { portals }\end{array}$ & & & & & & & 0.005 & 0.012 & 0.018 \\
\hline & Student ICT use-Blogs & & & & & & & 0.013 & 0.016 & 0.032 \\
\hline & $\begin{array}{l}\text { Student ICT use-Social network } \\
\text { sites, video, encyclopedia }\end{array}$ & & & & & & & -0.012 & 0.009 & -0.047 \\
\hline & Teacher ICT use & & & & & & & 0.008 & 0.010 & 0.034 \\
\hline & Social media-information & & & & & & & 0.004 & 0.038 & 0.004 \\
\hline & $\begin{array}{l}\text { Social media-behavior } \\
\text { promotion }\end{array}$ & & & & & & & 0.047 & 0.039 & 0.051 \\
\hline
\end{tabular}

Note: $\mathrm{R}^{2}=0.094(\Delta \mathrm{F}=21.28, p<0.01)$ for Step $1, \Delta \mathrm{R}^{2}=0.173$ for Step $2(\Delta \mathrm{F}=28.63, p<0.01), \Delta \mathrm{R}^{2}=0.008$ for Step 3 $(\Delta \mathrm{F}=1.08, p>0.05)$. Significant values $p<0.05$ are shown in bold.

Table 9. Regression analyses of predictors for sustainable development behavioral intention.

\begin{tabular}{|c|c|c|c|c|c|c|c|c|c|c|}
\hline \multirow[b]{2}{*}{ Step } & \multirow[b]{2}{*}{ Variables entered } & \multicolumn{3}{|c|}{ Step 1} & \multicolumn{3}{|c|}{ Step 2} & \multicolumn{3}{|c|}{ Step 3} \\
\hline & & $\mathrm{b}$ & SE & $\beta$ & $\mathrm{b}$ & SE & $\beta$ & $\mathrm{b}$ & SE & $\beta$ \\
\hline & Constant & 1.036 & 0.876 & & -1.181 & 0.934 & & -0.895 & 1.011 & \\
\hline \multirow[t]{4}{*}{1 Personal } & $\begin{array}{l}\text { Personal relevance of SD } \\
\text { issues-EE }\end{array}$ & 0.122 & 0.034 & 0.147 & 0.065 & 0.034 & 0.079 & 0.066 & 0.034 & 0.080 \\
\hline & $\begin{array}{l}\text { Personal relevance of SD } \\
\text { issues-Social }\end{array}$ & 0.062 & 0.027 & 0.091 & 0.081 & 0.027 & 0.118 & 0.074 & 0.027 & 0.108 \\
\hline & SD awareness & 0.766 & 0.114 & 0.254 & 0.421 & 0.121 & 0.140 & 0.422 & 0.120 & 0.140 \\
\hline & Sustainable lifestyle & 0.200 & 0.030 & 0.245 & 0.202 & 0.029 & 0.247 & 0.195 & 0.030 & 0.238 \\
\hline \multirow[t]{5}{*}{2 Academic } & $\begin{array}{l}\text { SD issues' inclusion in } \\
\text { curriculum-EE }\end{array}$ & & & & 0.047 & 0.030 & 0.066 & .032 & 0.030 & 0.045 \\
\hline & $\begin{array}{l}\text { SD issues' inclusion in } \\
\text { curriculum-Social }\end{array}$ & & & & -0.047 & 0.022 & -0.083 & -0.032 & 0.022 & -0.056 \\
\hline & $\begin{array}{c}\text { Study at } \\
\text { university-Information }\end{array}$ & & & & 0.263 & 0.119 & 0.097 & 0.183 & 0.124 & 0.067 \\
\hline & $\begin{array}{l}\text { Study at university-Behavior } \\
\text { promotion }\end{array}$ & & & & 0.684 & 0.130 & 0.210 & 0.643 & 0.138 & 0.197 \\
\hline & Perceived teaching methods & & & & 0.022 & 0.012 & 0.065 & 0.031 & 0.013 & 0.093 \\
\hline \multirow[t]{6}{*}{3 Digital } & $\begin{array}{l}\text { Student ICT use-E-books, } \\
\text { portals }\end{array}$ & & & & & & & 0.001 & 0.035 & 0.001 \\
\hline & Student ICT use-Blogs & & & & & & & -0.022 & 0.048 & -0.018 \\
\hline & $\begin{array}{l}\text { Student ICT use-Social network } \\
\text { sites, video, encyclopedia }\end{array}$ & & & & & & & -0.016 & 0.027 & -0.021 \\
\hline & Teacher ICT use & & & & & & & -0.064 & 0.028 & -0.096 \\
\hline & Social media-Information & & & & & & & 0.370 & 0.112 & 0.135 \\
\hline & $\begin{array}{l}\text { Social media-Behavior } \\
\text { promotion }\end{array}$ & & & & & & & 0.063 & 0.116 & 0.022 \\
\hline
\end{tabular}

Note: $\mathrm{R}^{2}=0.207(\Delta \mathrm{F}=40.03, p<0.01)$ for Step $1, \Delta \mathrm{R}^{2}=0.078$ for Step $2(\Delta \mathrm{F}=13.16, p<0.01), \Delta \mathrm{R}^{2}=0.023$ for Step 3 $(\Delta \mathrm{F}=3.29, p<0.01)$. Significant values $p<0.05$ are shown in bold. 
Table 10. Regression analyses of predictors for sustainable lifestyle.

\begin{tabular}{|c|c|c|c|c|c|c|c|c|c|c|}
\hline \multirow[b]{2}{*}{ Step } & \multirow[b]{2}{*}{ Variables entered } & \multicolumn{3}{|c|}{ Step 1} & \multicolumn{3}{|c|}{ Step 2} & \multicolumn{3}{|c|}{ Step 3} \\
\hline & & $\mathrm{b}$ & SE & $\beta$ & $\mathrm{b}$ & SE & $\beta$ & $\mathrm{b}$ & SE & $\beta$ \\
\hline & Constant & 8.843 & 1.130 & & 6.073 & 1.268 & & 5.314 & 1.356 & \\
\hline \multirow[t]{3}{*}{1 Personal } & $\begin{array}{l}\text { Personal relevance of SD } \\
\text { issues-EE }\end{array}$ & 0.000 & 0.046 & 0.000 & 0.001 & 0.047 & 0.001 & 0.010 & 0.046 & 0.010 \\
\hline & $\begin{array}{l}\text { Personal relevance of SD } \\
\text { issues-Social }\end{array}$ & 0.140 & 0.037 & 0.166 & 0.126 & 0.036 & 0.150 & 0.095 & 0.036 & 0.113 \\
\hline & SD awareness & 0.018 & 0.154 & 0.005 & 0.046 & 0.167 & 0.013 & -0.036 & 0.163 & -0.010 \\
\hline \multirow[t]{5}{*}{2 Academic } & $\begin{array}{l}\text { SD issues' inclusion in } \\
\text { curriculum-EE }\end{array}$ & & & & 0.054 & 0.041 & 0.061 & 0.051 & 0.041 & 0.058 \\
\hline & $\begin{array}{l}\text { SD issues' inclusion in the } \\
\text { curriculum-Social }\end{array}$ & & & & 0.088 & 0.030 & 0.127 & 0.068 & 0.030 & 0.098 \\
\hline & $\begin{array}{l}\text { Study at } \\
\text { university-Information }\end{array}$ & & & & -0.117 & 0.164 & -0.035 & -0.270 & 0.169 & -0.081 \\
\hline & $\begin{array}{c}\text { Study at university-Behavior } \\
\text { promotion }\end{array}$ & & & & -0.214 & 0.180 & -0.054 & -0.436 & 0.187 & -0.109 \\
\hline & Perceived teaching methods & & & & 0.060 & 0.017 & 0.146 & 0.040 & 0.017 & 0.097 \\
\hline \multirow[t]{6}{*}{3 Digital } & $\begin{array}{l}\text { Student ICT use-E-books, } \\
\text { portals }\end{array}$ & & & & & & & 0.131 & 0.047 & 0.124 \\
\hline & Student ICT use-Blogs & & & & & & & 0.003 & 0.065 & 0.002 \\
\hline & $\begin{array}{l}\text { Student ICT use-Social network } \\
\text { sites, video, encyclopedia }\end{array}$ & & & & & & & -0.020 & 0.037 & -0.021 \\
\hline & Teacher ICT use & & & & & & & 0.075 & 0.038 & 0.092 \\
\hline & Social media-Information & & & & & & & 0.358 & 0.152 & 0.107 \\
\hline & $\begin{array}{l}\text { Social media-Behavior } \\
\text { promotion }\end{array}$ & & & & & & & 0.324 & 0.156 & 0.094 \\
\hline
\end{tabular}

Note: $\mathrm{R}^{2}=0.028(\Delta \mathrm{F}=5.86, p<0.05)$ for Step $1, \Delta \mathrm{R}^{2}=0.057$ for Step $2(\Delta \mathrm{F}=7.62, p<0.01), \Delta \mathrm{R}^{2}=0.059$ for Step 3 $(\Delta \mathrm{F}=6.98, p<0.01)$. Significant values $p<0.05$ are shown in bold.

Table 11. Regression analyses of predictors for preferred teaching methods.

\begin{tabular}{|c|c|c|c|c|c|c|c|c|c|c|}
\hline \multirow[b]{2}{*}{ Step } & \multirow[b]{2}{*}{ Variables entered } & \multicolumn{3}{|c|}{ Step 1} & \multicolumn{3}{|c|}{ Step 2} & \multicolumn{3}{|c|}{ Step 3} \\
\hline & & $\mathrm{b}$ & SE & $\beta$ & $\mathrm{b}$ & $\mathrm{SE}$ & $\beta$ & $\mathrm{b}$ & SE & $\beta$ \\
\hline & Constant & 20.718 & 2.549 & & 9.192 & 2.631 & & 7.569 & 2.842 & \\
\hline \multirow[t]{4}{*}{1 Personal } & $\begin{array}{l}\text { Personal relevance of SD } \\
\text { issues-EE }\end{array}$ & 0.359 & 0.099 & 0.156 & 0.249 & 0.095 & 0.108 & 0.234 & 0.094 & 0.102 \\
\hline & $\begin{array}{l}\text { Personal relevance of SD } \\
\text { issues-Social }\end{array}$ & 0.126 & 0.080 & 0.066 & 0.152 & 0.075 & 0.079 & 0.137 & 0.075 & 0.072 \\
\hline & SD awareness & 0.432 & 0.332 & 0.052 & -0.242 & 0.341 & -0.029 & -0.176 & 0.338 & -0.021 \\
\hline & Sustainable lifestyle & 0.604 & 0.087 & 0.266 & 0.448 & 0.083 & 0.197 & 0.436 & 0.084 & 0.192 \\
\hline \multirow[t]{5}{*}{2 Academic } & $\begin{array}{l}\text { SD issues' inclusion in } \\
\text { curriculum-EE }\end{array}$ & & & & 0.145 & 0.084 & 0.072 & 0.082 & 0.084 & 0.041 \\
\hline & $\begin{array}{l}\text { SD issues' inclusion in } \\
\text { curriculum-Social }\end{array}$ & & & & 0.116 & 0.062 & 0.074 & 0.148 & 0.063 & 0.094 \\
\hline & $\begin{array}{c}\text { Study at } \\
\text { university-Information }\end{array}$ & & & & 0.134 & 0.334 & 0.018 & -0.021 & 0.350 & -0.003 \\
\hline & $\begin{array}{l}\text { Study at university-Behavior } \\
\text { promotion }\end{array}$ & & & & 1.239 & 0.367 & 0.137 & 1.083 & 0.389 & 0.120 \\
\hline & Perceived teaching methods & & & & 0.262 & 0.035 & 0.281 & 0.276 & 0.036 & 0.297 \\
\hline 3 Digital & $\begin{array}{l}\text { Student ICT use-E-books, } \\
\text { portals }\end{array}$ & & & & & & & 0.036 & 0.098 & 0.015 \\
\hline & Student ICT use-Blogs & & & & & & & -0.192 & 0.134 & -0.055 \\
\hline & $\begin{array}{l}\text { Student ICT use-Social network } \\
\text { sites, video, encyclopedia }\end{array}$ & & & & & & & 0.184 & 0.077 & 0.086 \\
\hline & Teacher ICT use & & & & & & & -0.154 & 0.079 & -0.083 \\
\hline & Social media-Information & & & & & & & 0.754 & 0.316 & 0.099 \\
\hline & $\begin{array}{l}\text { Social media-Behavior } \\
\text { promotion }\end{array}$ & & & & & & & 0.176 & 0.325 & 0.023 \\
\hline
\end{tabular}

Note: $\mathrm{R}^{2}=0.128(\Delta \mathrm{F}=22.49, p<0.05)$ for Step $1, \Delta \mathrm{R}^{2}=0.136$ for Step $2(\Delta \mathrm{F}=22.48, p<0.01), \Delta \mathrm{R}^{2}=0.025$ for Step 3

$(\Delta \mathrm{F}=3.56, p<0.01)$. Significant values $p<0.05$ are shown in bold. 
To conclude, person-related factors in our model explained the most substantial variance in behavioral intention, with less from preferred teaching methods and awareness, and only a small amount from the lifestyle. Awareness predicted behavioral intention, but not a real sustainable lifestyle. The personal relevance of environmental and economic issues was a significant predictor in three out of four models.

Factors related to the academic study were identified as significant predictors of awareness and preferred teaching methods. They had less influence on behavioral intention and actual sustainable lifestyle. Study as a behavior promoter was a significant predictor in all four models, and perceived teaching methods were a significant predictor in three models.

Digital factors accounted for a small amount of variance in our models. Digital predictors were most important in predicting sustainable lifestyle. Social media as a source of information was a significant predictor in three models.

For predictors reflecting social practices, we could summarize as follows. (1) Sustainable lifestyle contributed to the prediction of behavior intention and preferred teaching methods; (2) Perceived teaching methods contributed to the prediction of preferred teaching methods, sustainable lifestyle, and behavior intention; (3) Student ICT use-social network sites, video, and encyclopedia use contributed to the prediction of preferred teaching methods; (4) Seeing social media as a source of behavior promotion was a predictor for sustainable lifestyle; (5) Seeing social media as a source of information was a predictor for teaching methods, sustainable lifestyle, and behavioral intention.

\section{Discussion}

Our study revealed that environmental and economic SD issues (personally relevant or included in the curriculum) are part of the same latent factor, which contradicts previous findings. For example, Dlouha et al.'s [41] study of Central European countries, including Slovenia, reported that in higher education, economic issues are not connected to environmental issues. Related studies have indicated that students lack complex understanding of sustainability issues [66] and the dominance of environmental issues among university students [64], which was supported in our study, with higher average scores on environmental-economic factors than on social factors.

Hypothesis 1, stating that academic, personal, and digital factors in our model make different contributions, is confirmed. Our study showed that personal factors are the most important in predicting behavioral intention ( $20.7 \%$ of explained variance), academic factors are the most important in predicting SD awareness (17.3\% of explained variance), and digital factors are the most important in predicting sustainable lifestyle (5.9\% of explained variance). Related studies revealed the effect of informal learning in interactions within the social group, of social media and computer networking on sustainability action at a personal level [65], and of the institutional level as social capital supporting sustainability integration in higher education [4]. Personal predictors in our model contributed to the prediction of behavioral intention, and a lesser extent to awareness. Related studies revealed that awareness or attitude is not a direct predictor of behavior [67], and the weak influence of behavior intention on behavior [26,28]. Further, our results further revealed some interesting patterns. The results showed that there is no correlation and therefore no predictive ability between SD awareness and sustainable lifestyle, meaning that pure awareness does not necessarily result in sustainable lifestyles. The personal relevance of environmental-economic issues is the only significant personal predictor of awareness $(\beta=0.206)$. However, for sustainable lifestyles, the only significant personal predictor is the personal relevance of social issues for $\mathrm{SD}(\beta=0.113)$, possibly showing that individuals' ethical, pro-social orientation may underpin such a mode of living.

As indicated in related work, SDE currently aims at influencing values and attitudes [26]. Thus, the influence of academic study on awareness was expected and confirmed in our study, as assumed in Hypothesis 2. Among the academic factors, seeing study as a source of information $(\beta=0.363)$ and as a source of behavior promotion $(\beta=0.089)$ were significant predictors of SD awareness. Academic factors also predicted behavioral intention (explaining $7.8 \%$ of explained variance) and sustainable 
lifestyle (explaining 5.7\% of explained variance). This is consistent with findings by Meyer [2] that pro-environmental behavior increases with additional time spent in higher education environments.

Digital factors are predictors of three outcome variables (explaining up to $5.9 \%$ of the variance in outcome variables). However, they are the most important for predicting sustainable lifestyle in our model. Among digital factors, student ICT use of e-books and portals ( $\beta=0.124)$, teacher ICT use $(\beta=0.092)$, seeing social media as a source of information $(\beta=0.107)$, and behavior promotion ( $\beta=0.094)$ are all predictors of a sustainable lifestyle. However, student ICT use - blogs and social network sites, video, and encyclopedia do not predict a sustainable lifestyle.

The predictors contributing to SD awareness don't reflect social practices; none of the factors indicating social practices (sustainable lifestyle, teaching methods supporting authentic learning, and social media) was a significant predictor of SD awareness.

We can confirm Hypothesis 2. It is identified that courses prepare students for SD awareness, but not sufficiently for SD behavior, and we hypothesized that a significant predictor for SD behavior, measured as sustainable lifestyle and SD behavioral intention, would be learning in social practices.

Social practices that support learning as boundary crossing and offer to learn at the level of procedural and problem-solving knowledge make significant contributions to sustainable lifestyle and behavioral intention. The role of online social media in bridging between formal and informal learning [49] provides optimal learning contexts reaching beyond awareness to the level of knowledge application. Perceived teaching methods are significant predictors, but their importance in comparison to other predictors is relatively small. Among digital practices, online social media, if perceived as a source of information, significantly contributes to the prediction of lifestyle $(\beta=0.107)$ and behavioral intention $(\beta=0.135)$. Based on the findings, we can conclude that connecting formal and informal learning integrating digital practices [68] could contribute to personal agency by integrating awareness and lifestyle.

Focusing on students' perceptions of the learning context, we examined preferred teaching method (Figure 3) for SD as the outcome variable, hypothesizing that preferred teaching methods are predicted by learning in social practices (lifestyle, perceived teaching methods, and digital practices). We can confirm this hypothesis, because the perceived teaching methods $(\beta=0.297)$ and sustainable lifestyle ( $\beta=0.192$ ) are the most important predictors of preferred teaching methods in our model. Among the digital practices, the online social media as a source of information $(\beta=0.099)$ and student ICT use of pervasive social media-social network sites, video, and encyclopedia $(\beta=0.086)$, are significant predictors, but relatively less so than sustainable lifestyle and perceived teaching methods. Thus, social practices have a significant impact on preferred teaching methods (see Table 11).

We summarize the roles of the three predictors reflecting social practices below. Nikolaou and Conlon [66] revealed the lack of students' knowledge and understanding of the complexity of sustainable development, and that they perceive a much higher importance of SD at the professional level than at a personal level. Based on the findings of our study, we argue for teaching methods supporting authentic learning that integrate personal and professional contexts and provide continuum between formal and informal learning [21]. 


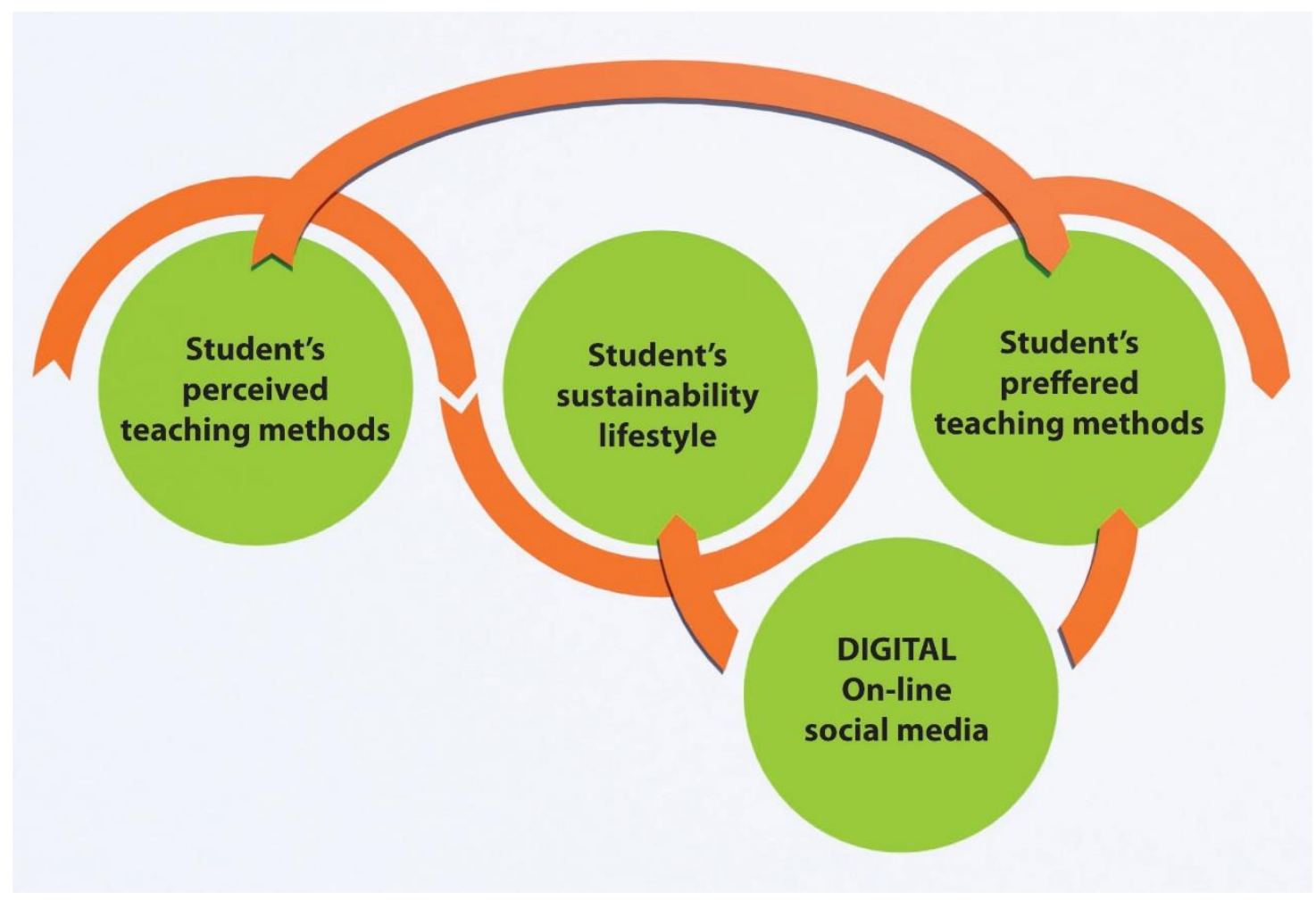

Figure 3. Perceived teaching methods, day-to-day lifestyle practices, and online social media influence preferred teaching methods.

\subsection{The Role of Social Media and Digital Practices}

The notion of boundary crossing provides an interpretation of how learning occurs between academic contexts and day-to-day practices in which social media is the predominant digital practice. In studies on online social media in higher education, social media networks have been recognized as facilitators for aggregating, sharing, participating in collective knowledge generation, and meaning-making [53]. A significant finding of our study is that merely using online social media does not predict a sustainable lifestyle. They must also be seen as a source of information for SD in order to be a significant predictor of behavior. Based on the findings, we may summarize that more informed ICT use (targeted use of social media, use of online resources) might contribute to living a sustainable lifestyle and thus could be seen as boundary crosser between the personal, academic, and professional spheres.

\subsection{The Role of Teaching Methods Supporting Authentic Learning}

Informal learning that occurs in formal higher learning environments may be an essential source of sustainable behavior [2]. In our model, perceived teaching methods for learning SD were examined as a possible predictor. Within the academic context, perceived teaching methods supporting authentic learning integrate across the academic-professional boundary, and provide engagement and connection with real-life practices. In our model, perceived teaching methods significantly contribute to the prediction of behavioral intention and sustainable lifestyle, but the relative importance of this predictor is small. On the other hand, perceived teaching methods for SD are the most influential predictor of preferred teaching methods, which confirms our boundary-crossing-based model. This should be noted when developing learner-centered education for SD. 


\subsection{The Role of Sustainable Lifestyle}

In our study, we used the concept of lifestyle as a measure of behavior. An interesting finding was that our sample demonstrated two latent constructs: namely, sustainable lifestyle as a recognizable mode of living, and as a factor representing more day-to-day pro-environmental activities. The examination of students' perceptions and practices indicated a connectedness of lifestyle and learning for SD. The sustainable lifestyle was suggested as the most important predictor of behavioral intention and preferred teaching methods, which was demonstrated in the personal mode of living and day-to-day activities. As noted by Mintz and Tal [21], sustainable lifestyle must be taken into account when designing the objectives of education for SD.

\section{Conclusions and Future Directions}

Three factors have implications for teaching and learning practice as drivers of change in higher educational institutions. First, the inclusion of SD themes is not particularly relevant if not contextualized, and if awareness of SD or declarative knowledge is not applied in practice. Teaching methods supporting authentic learning that connect academic and professional contexts, as well as the academic and lifeworld contexts of the student are required for higher-order learning outcomes and SD literacy. Higher educational institutions need to consider educational technology integration with a student in a center and its digital social practices.

Secondly, in higher education for SD, online social media support a whole-system approach and, as a vital source of social capital, facilitate activities and resources for the successful integration of SD through a process and structure of relationships [56,57]. Chiong et al. [6] indicated the lack of study in the area of social capital associated with SD awareness as an intrinsic interest driving behavior change. Interestingly, our study did not show online social practices contributing much to SD awareness. Social media provide opportunities for informal learning and building social capital while bridging boundaries between lifestyle, academic, and professional contexts.

Thirdly, SD literacy teaching and learning that takes into account and connects to a day-to-day personal lifestyle where informal learning occurs has excellent potential for the successful development of higher-order learning outcomes for SD [21].

Regarding the limitations of the study, we could summarize as follows: the amount of explained variance was $26.7 \%$ for SD awareness, $30.8 \%$ for SD behavioral intention, $14.5 \%$ for SD lifestyle, and $28.9 \%$ for preferred teaching methods. This indicates a certain amount of unexplained variance, which could be attributed to other factors, and thus is a challenge for future research. The limitation of our study is that the data is based on self-report.

Understanding students' perceptions and practices are critical for achieving higher-level learning outcomes. In this study, we examine whether learning in social practices, which can include informal learning with procedural and problem-solving knowledge development, predicts sustainable development awareness, behavioral intention, and sustainable lifestyle. The initial hypotheses used our model of learning as boundary crossing as a basis, highlighting the role of the predictors and reflecting social practices. Developing sustainable development literacy within social systems and crossing boundaries, seeking productive ways for relating experiences and practices, has excellent potential for achieving higher-order learning outcomes in authentic contexts. Referential studies indicated a need for a whole-system approach; we believe that changing the pedagogical practice for learning as boundary crossing could contribute to a whole system approach.

Author Contributions: Conceptualization, A.I.S.; Methodology, A.I.S.; M.L.; Validation, M.L.; Formal Analysis, M.L.; Investigation, M.T.; Resources, A.I.S., M.T.; Data Curation, M.T.; Writing-Original Draft Preparation, A.I.S.; M.L.; Writing-Review \& Editing, A.I.S., M.L., L.L.; Visualization, A.I.S.; All authors read and approved the final version.

Funding: This research received no external funding.

Conflicts of Interest: The authors declare no conflict of interest. 


\section{References}

1. Eggenberger, M.; Partidário, M.R. Development of a framework to assist the integration of environmental, social and economic issues in spatial planning. Impact Assess. Proj. Apprais. 2000, 18, 201-207. [CrossRef]

2. Meyer, A. Heterogeneity in the preferences and pro-environmental behavior of college students: The effects of years on campus, demographics, and external factors. J. Clean. Prod. 2016, 112, 3451-3463. [CrossRef]

3. Dale, A.; Newman, L. Sustainable development, education and literacy. Int. J. Sustain. High. Educ. 2005, 6, 351-362. [CrossRef]

4. Mader, C. How to assess transformative performance towards sustainable development in higher education institutions. J. Educ. Sustain. Dev. 2012, 6, 79-89. [CrossRef]

5. Wals, A.E.J. Shaping the Education of Tomorrow: 2012 Full-Length Report on the UN Decade of Education for Sustainable Development; UNESCO: Paris, France, 2012; ISBN 978-92-3-001076-8.

6. Chiong, K.S.; Mohamad, Z.F.; Abdul Aziz, A.R. Factors encouraging sustainability integration into institutions of higher education. Int. J. Environ. Sci. Technol. 2017, 14, 911-922. [CrossRef]

7. Wan Alwi, S.R.; Abdul Manan, Z.; Klemeš, J.J.; Huisingh, D. Sustainability engineering for the future. J. Clean. Prod. 2014, 71, 1-10. [CrossRef]

8. Ardoin, N.M. Toward an Interdisciplinary Understanding of Place: Lessons for Environmental Education. Can. J. Environ. Educ. 2006, 11, 112-126.

9. Wiseman, A.W.; Astiz, M.F.; Baker, D.P. Comparative education research framed by neo-institutional theory: A review of diverse approaches and conflicting assumptions. Compare 2014, 44, 688-709. [CrossRef]

10. Akiba, M. Editor's Introduction: Understanding Cross-National Differences in Globalized Teacher Reforms. Educ. Res. 2017, 46, 153-168. [CrossRef]

11. Accreditation Board for Engineering and Technology (ABET). Criteria for Accrediting Engineering Programs. 2016. Available online: http:/ / www.abet.org/accreditation/accreditation-criteria/criteria-for-accreditingengineering-technology-programs-2016-2017/ (accessed on 12 June 2018).

12. Shuman, L.J.; Besterfield-Sacre, M.; McGourty, J. The ABET "professional skills" — Can they be taught? Can they be assessed? J. Eng. Educ. 2005, 94, 41-55. [CrossRef]

13. Rouvrais, R.; Le Locat, C.; Flament, S. Return on Experience from Sustainability Audits in European Engineering Educational Institutions. In Proceedings of the 41th Annual Conference: Engineering Education Fast Forward (Societé Européenne de Formation des Ingénieurs), Leuven, Belgium, 16-20 September 2013; pp. 16-20.

14. Molderez, I.; Fonseca, E. The efficacy of real-world experiences and service learning for fostering competences for sustainable development in higher education. J. Clean. Prod. 2018, 172, 4397-4410. [CrossRef]

15. Holdsworth, S.; Hegarthy, K. From praxis to delivery: A Higher Education Learning Design Framework (HELD). J. Clean. Prod. 2016, 122, 176-185. [CrossRef]

16. Thomas, I. Critical Thinking, Transformative Learning, Sustainable Education, and Problem-Based Learning in Universities. J. Transform. Educ. 2009, 7, 245-264. [CrossRef]

17. Shephard, K.; Harraway, J.; Lovelock, B.; Mirosa, M.; Skeaff, S.; Slooten, L.; Strack, M.; Furnari, M.; Jowett, T.; Deaker, L. Seeking learning outcomes appropriate for 'education for sustainable development' and for higher education. Assess. Eval. High. Educ. 2015, 40, 855-866. [CrossRef]

18. Wiek, A.; Withycombe, L.; Redman, C.L. Key competencies in sustainability: A reference framework for academic program development. Sustain. Sci. 2011, 6, 203-218. [CrossRef]

19. Gagné, R.M.; Briggs, L.J.; Wagner, W.W. Principles of Instructional Design, 4th ed.; Harcourt Brace College Publishers: Fort Worth, TX, USA, 1992; ISBN 0-03-034757-2.

20. Marentič Požarnik, B. Psychology of Teaching and Learning; DZS: Ljubljana, Slovenia, 2003; ISBN 86-341-2624-2.

21. Mintz, K.; Tal, T. Sustainability in higher education courses: Multiple learning outcomes. Stud. Educ. Eval. 2014, 41, 113-123. [CrossRef]

22. Valenčič Zuljan, M.; Peklaj, C.; Pečjak, S.; Puklek, M.; Kalin, J. Didactic competencies of teachers from the learner's viewpoint. Educ. Stud. 2012, 1, 51-62. [CrossRef]

23. Barth, M.; Burandt, S. Adding the "e-" to Learning for Sustainable Development: Challenges and Innovation. Sustainability 2013, 5, 2609-2622. [CrossRef]

24. Kollmuss, A.; Agyeman, J. Mind the gap: Why do people act environmentally and what are the barriers to pro-environmental behaviour? Environ. Educ. Res. 2002, 8, 239-260. [CrossRef] 
25. Salonen, A.O.; Åhlberg, M.K. The Path towards Planetary Responsibility-Expanding the Domain of Human Responsibility Is a Fundamental Goal for Lifelong Learning in a High-Consumption Society. J. Sustain. Dev. 2012, 5, 13-26. [CrossRef]

26. Arbuthnott, K.D. Attitudes for sustainable development beyond attitude change. Int. J. Sustain. High. Educ. 2009, 10, 152-163. [CrossRef]

27. Ballantyne, R.; Packer, J. Promoting environmentally sustainable attitudes and behaviour through free-choice learning experiences: What is the state of the game? Environ. Educ. Res. 2005, 11, 281-295. [CrossRef]

28. English Oxford Living Dictionary. Available online: https://en.oxforddictionaries.com/definition/ awareness (accessed on 12 June 2018).

29. Fishbein, M. Theory of Reasoned Action: Some Applications and Implications. In 1979 Nebraska Symposium on Motivation; Howe, H., Page, M., Eds.; University of Nebraska Press: Lincoln, NE, USA, 1980; pp. 65-116.

30. Webb, T.L.; Sheeran, P. Does changing behavioural intentions engender behaviour change? A meta-analysis of the experimental evidence. Psychol. Bull. 2006, 132, 249-268. [CrossRef] [PubMed]

31. Bamberg, S.; Möser, G. Twenty years after Hines, Hungerford, and Tomera: A new meta-analysis of psycho-social determinants of pro-environmental behaviour. J. Environ. Psychol. 2007, 27, 14-25. [CrossRef]

32. Sobel, M.E. Lifestyle and Social Structure: Concepts, Definitions, Analyses; Academic Press: New York, NY, USA, 1981; ISBN 0-12-654280-5.

33. Bloom, B.S.; Engelhart, M.; Furst, E.; Hil, W.; Krathwohl, D. Taxonomy of Educational Objectives. Classification of Educational Goals. Handbook I. Cognitive Domain; Longman: New York, NY, USA, 1956; ISBN 0-582-28010-9.

34. Krathwohl, D.; Bloom, B.S.; Masia, B.B. Taxonomy of Educational Objectives, the Classification of Educational Goals, Handbook II: Affective Domain; David McKay Co Inc.: New York, NY, USA, 1964; ISBN 0-679-30210-7.

35. Kahn, P. Critical perspectives on methodology in pedagogic Research. Teach. High. Educ. 2015, $20,442-454$. [CrossRef]

36. Carew, A.L.; Mitchell, C.A. Characterizing undergraduate engineering students' understanding of sustainability. Eur. J. Eng. Educ. 2002, 27, 349-361. [CrossRef]

37. Biggs, J.B.; More, P.J. The Process of Learning, 3rd ed.; Prentice Hall: Sydney, Australia, 1993; ISBN 072481003X.

38. UNECE Strategy for Education for Sustainable Development Adopted at the High-Level Meeting Vilnius, Lithuania, 17-18 March 2005; UNECE CEP (United Nations Economic Commission End Social Council Committee of Environmental Policy). 2005. Available online: https:/ /www.unece.org/fileadmin/DAM/ env/documents/2005/cep/ac.13/cep.ac.13.2005.3.rev.1.e.pdf (accessed on 12 June 2018).

39. Donovan, M.S.; Bransford, J.D.; Pellegrino, J.W. How People Learn: Bridging Research and Practice; National Academy Press: Washington, DC, USA, 1999; ISBN 0-309-06536-4.

40. Filho, W.L.; Shiel, C.; Paço, A. Implementing and operationalising integrative approaches to sustainability in higher education: The role of project-oriented learning. J. Clean. Prod. 2016, 133, 126-135. [CrossRef]

41. Dlouha, J.; Glavič, P.; Barton, A. Higher education in Central European countries e Critical factors for sustainability transition. J. Clean. Prod. 2017, 151, 670-684. [CrossRef]

42. Akkerman, S.F.; Bakker, A. Crossing boundaries between school and work during apprenticeships. Vocat. Learn. 2012, 5, 153-173. [CrossRef]

43. Schunk, D.H. Learning Theories an Educational Perspective, 6th ed.; Pearson: Boston, MA, USA, 2012; ISBN 978-0-13-707195-1.

44. Engeström, Y. Expansive Learning at Work: Toward an activity theoretical reconceptualization. J. Educ. Work 2001, 14, 133-156. [CrossRef]

45. Selwyn, N. The use of computer technology in university teaching and learning: A critical perspective. J. Comput. Assist. Learn. 2007, 23, 83-94. [CrossRef]

46. Biggs, J.; Tang, C. Teaching for Quality Learning at University, 4th ed.; Open University Press and McGraw-Hill International: Maidenhead, UK, 2011; ISBN 0-335-21168-2.

47. Kyndt, E.; Gijbels, D.; Grosemans, I.; Donche, V. Teachers' Everyday Professional Development: Mapping Informal Learning Activities, Antecedents, and Learning Outcomes. Rev. Educ. Res. 2016, 86, 1111-1150. [CrossRef]

48. Straub, E.T. Understanding Technology Adoption: Theory and Future Directions for Informal Learning. Rev. Educ. Res. 2009, 79, 625-649. [CrossRef]

49. Mills, L.A.; Knezek, G.; Khaddage, F. Information Seeking, Information Sharing, and going mobile: Three bridges to informal learning. Comput. Hum. Behav. 2014, 32, 324-334. [CrossRef] 
50. Lin, L. Cultural dimensions of authenticity. New Dir. Adult Contin. Educ. 2006, 111, 63-72. [CrossRef]

51. Newmann, F.M.; Marks, H.M.; Gamoran, A. Authentic pedagogy and student performance. Am. J. Educ. 1996, 104, 280-312. [CrossRef]

52. Reeves, T.C.; Herrington, J.; Oliver, R. Authentic activities and online learning. In Quality Conversations: Research and Development in Higher Education; Herrington, T., Ed.; HERDSA: Perth, Australia, 2002; Volume 25, pp. 562-567, ISBN 090855754X.

53. Baeten, M.; Struyven, K.; Dochy, F. Student-centred teaching methods: Can they optimise students' approaches to learning in professional higher education? Stud. Educ. Eval. 2013, 39, 14-22. [CrossRef]

54. Dieleman, H.; Huisingh, D. Games by which to learn and teach about sustainable development: Exploring the relevance of games and experiential learning for sustainability. J. Clean. Prod. 2006, 14, 837-847. [CrossRef]

55. Backingham, D.; Martinez-Rodriguez, J. Interactive Youth: New Citizenship between Social Networks and School Settings. Comunicar 2013, 40, 10-13. [CrossRef]

56. Coleman, J.S. Social Capital in the Creation of Human Capital. Am. J. Sociol. 1988, 94, 95-120. [CrossRef]

57. Putnam, R.D. Making Democracy Work-Civic Traditions in Modern Italy; Princeton University Press: Princeton, UK, 1993; ISBN 0-691-07889-0.

58. York, D.; Owston, R. Enabling Learning with User-Created Web Video in Higher Education; Task Report; York University: Toronto, ON, Canada, 2012; Available online: http://www.yorku.ca/rowston/ AERA2012Dennis.pdf (accessed on 12 June 2018).

59. Dabbagh, N.; Kitsantas, A. Personal Learning Environments, social media, and self-regulated learning: A natural formula for connecting formal and informal learning. Internet High. Educ. 2012, 15, 3-8. [CrossRef]

60. Istenic Starcic, A.I.; Barrow, M.; Zajc, M.; Lebenicnik, M. Students' Attitudes on Social Network Sites and their Actual Use for Career Management Competences and Professional Identity Development. iJET 2017, 12, 65-81. [CrossRef]

61. Prosser, M.; Trigwel, K. Understanding Learning and Teaching The experience in Higher Education; SRHE \& Open University Press: Buckingham, UK, 2000; ISBN 0-335-19381-7.

62. Sagadin, J. Validity of qualitative empirical research in education. Sodobna Pedagogika 2009, 60, 140-158.

63. Lawshe, C.H.A. Quantitative approach to content validity. Pers. Psychol. 1975, 28, 563-575. [CrossRef]

64. Kagawa, F. Dissonance in students' perceptions of sustainable development and sustainability. Int. J. Sustain. High. Educ. 2007, 8, 317-338. [CrossRef]

65. Reid, A.; Petocz, P. University lecturers' understanding of sustainability. High Educ. 2006, 51, $105-123$. [CrossRef]

66. Nicolaou, I.; Conlon, E. What do final year engineering students know about sustainable development? Eur. J. Eng. Educ. 2012, 37, 267-277. [CrossRef]

67. Sahin, E.; Ertepinar, H.; Teksoz, G. University students' behaviours pertaining to sustainability: A structural equation model with sustainability-related attributes. Int. J. Environ. Sci. Educ. 2012, 7, 459-478.

68. Greenhow, C.; Lewin, C. Social media and education: Reconceptualizing the boundaries of formal and informal learning. Learn. Media Technol. 2016, 41, 6-30. [CrossRef]

(C) 2018 by the authors. Licensee MDPI, Basel, Switzerland. This article is an open access article distributed under the terms and conditions of the Creative Commons Attribution (CC BY) license (http:/ / creativecommons.org/licenses/by/4.0/). 